\title{
САМОРЕГУЛИРОВАНИЕ В ЖКХ МЕГАПОЛИСА
}

\author{
И.В. ДРОЗДОВА \\ Профессор кафедры "Менеджмент таможенного и страхового сервиса" \\ ФГБОУ ВО «СПбГЭУ», д-р экон. наук \\ А.С. ЧУРИЛИН \\ кафедры "Менеджмент таможенного и страхового сервиса" \\ ФГБОУ ВО «СПбГЭУ», к.т.н \\ Статья подготовлена в рамках реализащии проекта 2.2.5 «Проведение научных \\ исследований в сфере потребительских, таможенных и криминалистических услуг населению в \\ рамках научно-образовательного иентра «Технологии товароведческой,таможенной $и$ \\ криминалистической экспертизы» Программы стратегического развития ФГБОУ ВПО
} «СПбГЭУ» на 2014-2016 годы.

Аннотация

Статья посвящена рассмотрению управленческих аспектов развития системы саморегулирования в ЖКХ мегаполиса и снижения рисков управления ЖКХ.

В ней рассмотрен организационный механизм управления системой ХКХ и управления рисками в сфере ЖКХ.

Ключевые слова: ЖКХ, саморегулирование, система, риск

\section{Abstract}

The article is devoted the administrative aspects of the development of self-regulation in the housing metropolis and risk reduction management utilities.

It is considered an institutional mechanism control housing system and risk management in the housing sector.

Keywords: housing, self-regulation, system, risk

\section{ВВЕДЕНИЕ}

В соответствии со Статьей 3. Саморегулируемые организации, N 315-Ф3, от 1 декабря 2007 года «О Саморегулируемых организациях»:

- Саморегулируемыми организациями признаются некоммерческие организации, созданные в целях саморегулирования, основанные на членстве, объединяющие субъектов предпринимательской деятельности исходя из единства отрасли производства товаров (работ, услуг) или рынка произведенных товаров (работ, услуг) либо объединяющие субъектов профессиональной деятельности определенного вида. 
- Объединение в одной саморегулируемой организации субъектов предпринимательской деятельности и субъектов профессиональной деятельности определенного вида может предусматриваться федеральными законами.

- Саморегулируемой организацией признается некоммерческая организация, созданная в соответствии с Гражданским кодексом Российской Федерации и Федеральным законом от 12 января 1996 года N 7-Ф3 "О некоммерческих организациях", только при условии ее соответствия всем установленным настоящим Федеральным законом требованиям. К числу указанных требований помимо установленных в части 1 настоящей статьи относятся:

- объединение в составе саморегулируемой организации в качестве ее членов не менее двадцати пяти субъектов предпринимательской деятельности или не менее ста субъектов профессиональной деятельности определенного вида, если федеральными законами в отношении саморегулируемых организаций, объединяющих субъектов предпринимательской или профессиональной деятельности, не установлено иное;

- наличие стандартов и правил предпринимательской или профессиональной деятельности, обязательных для выполнения всеми членами саморегулируемой организации;

- обеспечение саморегулируемой организацией дополнительной имущественной ответственности каждого члена сро перед потребителями произведенных товаров (работ, услуг) и иными лицами посредством установления в отношении членов саморегулируемой организации требования страхования, указанного в пункте 1 части 1 статьи 13 настоящего Федерального закона, и посредством формирования компенсационного фонда саморегулируемой организации.

- Для осуществления деятельности в качестве саморегулируемой организации некоммерческой организацией должны быть созданы специализированные органы, осуществляющие контроль за соблюдением членами саморегулируемой организации требований стандартов и правил предпринимательской или профессиональной деятельности и рассмотрение дел о применении в отношении членов саморегулируемой организации мер дисциплинарного воздействия, предусмотренных внутренними документами саморегулируемой организации.

- Требования, предусмотренные пунктами 1 - 3 части 3 настоящей статьи и предъявляемые к саморегулируемым организациям, и требования, предъявляемые к некоммерческим организациям для признания их саморегулируемыми организациями, являются обязательными. Федеральными законами могут быть установлены иные требования к некоммерческим организациям, объединяющим субъектов предпринимательской или профессиональной деятельности, для признания их саморегулируемыми организациями, а также могут быть установлены повышенные требования по сравнению с указанными в настоящем Федеральном законе требованиями к саморегулируемым организациям.

- Некоммерческая организация приобретает статус саморегулируемой организации с даты внесения сведений о некоммерческой организации в государственный реестр сро (саморегулируемых организаций) [1]. 
Основным преимуществом саморегулирования деятельности управляющих компаний в ЖКХ мегаполиса перед другими способами является солидарная и коллективная ответственность членов (в форме Компенсационного фонда). Это позволяет гарантировать реальную финансовую ответственность и компенсацию вреда в случае оказания некачественных услуг. Кроме того, институты саморегулирования стимулируют создание четких профессиональных стандартов деятельности и ведут к самоочистке рынка от недобросовестных участников (за которых приходится платить самим участникам рынка). Впервые появляется реальная возможность установить контроль за соблюдением профессиональных стандартов деятельности сферы ЖКХ и защитить права граждан [2;3].

Учитывая вышеизложенное, а также тенденцию на сокращение государственного регулирования сферы услуг - у саморегулирования нет альтернативы. Именно саморегулирование позволяет «запустить экономические принципы» и стимулировать управляющие организации вкладывать средства в безопасность и качество предоставляемых услуг. В свою очередь, именно саморегулируемые организации (СРО) при должном регулировании и государственном надзоре за их деятельностью могут стать эффективным инструментом контроля на рынке.

\section{РЕЗУЛЬТАТЫ И ИХ ОБСУЖДЕННИЕ}

Значительный вклад в исследование проблем экономики и управления строительством внесли отечественные ученые А.Н. Асаул, А.П. Борисов, И.И. Боровков, В.В. Бузырев, С.Н. Булгаков, Б.В. Генералов, Л.Я. Герцберг, П.Г. Грабовый, В.Г. Давидович, Г.Д. Дроздов, К.И. Клименко, Б.М. Колотилкин, А.В. Кочетков, А.А. Лаушкина, Ю.П. Панибратов, Е.В. Песоцкая, В.М. Серов, В.К. Соколов, В.И. Травин, Т.Н. Чистякова, Н.П. Шепелев, М.С. Шумилов, А.К. Шрейбер и др.

Расмотрению вопросов развития местного самоуправления и саморегулирования ЖКХ посвящены научные работы Г.Д. Дроздова, А.О. Кондрашова, Д.С.Назарова и др.

В теоретических исследованиях в области экономики и управления инвестиционностроительным комплексом проблема управления процессами саморегулирования крупных городов (мегаполисов) остается малоисследованной. Для ее решения необходима разработка методологии управления жилищной деятельностью с учетом развития различных форм местного самоуправления на основе моделирования и прогнозирования и максимально эффективного использования принципиально новых градостроительных, управленческих решений и экономического механизма, новых методов и моделей взаимодействия ее участников в условиях единого информационного пространства.

Проведенные исследования позволили установить риски введения саморегулирования, к которым, по мнению автора, можно отнести следующие [4]:

- монополизация отрасли, которая выражается, во-первых, ценовым сговором со стороны управляющих компаний в мегаполисе и, во-вторых, зависимостью от региональных и муниципальных властей, включая прямую подчиненность; 
- появление чрезмерного количества саморегулируемых организаций, включая фиктивные.

По состоянию на 1 января 2013 года количество частных управляющих организаций, осуществляющих деятельность по управлению многоквартирными домами, например, в Российской Федерации превысило 12 тысяч. При этом около 80\% многоквартирных домов фактически управляется именно управляющими организациями (непосредственно или по договору с Товариществами собственников жилья). В то же время, регулирование в этой сфере явно недостаточное: отсутствуют правила и требования к профессиональной деятельности, не разработаны стандарты качества работ и услуг по управлению многоквартирными домами, фактически отсутствует ответственность участников рынка (в том числе финансовая). Все это приводит к злоупотреблениям, недобросовестной конкуренции и некачественным услугам, что непосредственно затрагивает граждан.

Для решения этих проблем, по нашему мнению, целесообразны следу-ющие институциональные изменения, позволяющие снизить возможные риски саморегулирования в ЖКХ мегаполиса [5]:

создание механизм народного контроля, работу которого возможно координировать при помощи региональных Общественных палат под председательством Общественной палаты Российской Федерации. Его создание может стать одним из самых эффективных и действенных механизмов, поскольку сами жильцы будут заинтересованы в эффективном управлении многоквартирным домом, в котором они живут [6];

- внесение изменений в действующее законодательство в части установления обязательных минимальных требований к организациям, осуществляющим деятельность в сфере управления многоквартирным жилым фондом, к квалификации персонала подобных организаций, определения порядка организации их деятельности, предусмотрение обязательности членства управляющих компаний в профессиональных сообществах (саморегулируемых организациях), определения направления и особенности деятельности подобных СРО;

- внесение изменений в действующее законодательство в части разграничения деятельности управляющих компаний и ресурсоснабжающих организаций при оказании коммунальных услуг населению. Необходимо предоставить управляющим компаниям право заниматься деятельностью по управлению многоквартирными домами, содержанию и текущему ремонту общего имущества в многоквартирном доме, а ресурсоснабжающим организациям - право оказывать коммунальные услуги населению в виде поставки соответствующих коммунальных ресурсов;

- внесение изменений в Жилищный Кодекс Российской Федерации в части установления необходимости расчетов за жилищно-коммунальные услуги через Единые расчетно-кассовые центры (ЕРКЦ). Необходимо: ввести в законодательство поправку по закреплению указанного термина; внести изменения в Федеральный закон от 03.06.2009 № 103-Ф3 "О деятельности по приему платежей физических лиц, осуществляемой платежными агентами" в части закрепления осуществления приема платежей за жилищно-коммунальные услуги через ЕРКЦ; законодательно закрепить требования к процедуре создания и деятельности указанных платежных агентов: ЕРКЦ 
должен быть только муниципальным, распределяющим полученные от населения средства по соответствующим поставщикам ресурсов и услуг;

- внесение изменений в действующее законодательство в части закрепления обязательности отдельного учета управляющей компанией денежных средств, поступивших от населения в оплату коммунальных услуг. Целесообразно законодательно закрепить целевой характер данных денежных средств, предусмотреть меры контроля за их расходованием и ответственность за их нецелевое использование. Необходимо предусмотреть порядок и условия применения расчетов по инкассо и аккредитиву;

- внесение изменений в действующее законодательство в части закрепления ответственности управляющих компаний за не перечисление поставщикам коммунальных ресурсов денежных средств, поступивших от населения в счет оплаты коммунальных услуг; внесение изменений в действующее законодательство в части передачи прав собственникам жилых помещений (домов), проживающим в малоэтажном жилом фонде, самостоятельно выбирать управляющие компании, создавать Жилищно-строительные кооперативы, а также Товарищества собственников жилья для строительства и дальнейшей эксплуатации малоэтажных поселков;

- внесение изменений в Жилищный Кодекс Российской Федерации, позволяющих ресурсоснабжающим организациям заключать договора с нанимателями и собственниками жилых помещений. В силу статьи 426 Гражданского кодекса Российской Федерации договор энергоснабжения является публичным. Поэтому ресурсоснабжающие организации должны иметь приоритет в выстраивании отношений с нанимателями и собственниками перед управляющими многоквартирными домами организациями;

- разработка и утверждение в установленном законом порядке методики расчета количества тепловой энергии. Она должна применяться управляющими компаниями и ресурсоснабжающими организациями при отсутствии приборов учета $[7 ; 8]$;

- разработка документа, регламентирующего договорные взаимоотношения теплоснабжающих организаций и управляющих компаний с образцами типовых договоров теплоснабжения;

увеличение ответственности неплательщиков и расширение спектра возможных мер воздействия к ним. При этом целесообразно создание специализированного жилищного фонда для таких должников. С одной стороны, должна быть гарантирована конституционная норма предоставления должникам жилища. С другой стороны, правовой статус такого жилища и переселения в него должны быть строго регламентированы законом;

- разработка механизмов сдерживания роста платежей за коммунальные услуги путём установления долгосрочных, на срок не менее трёх лет, тарифов ресурсоснабжающих организаций. При этом в них необходимо учитывать соответствующим образом утверждённые инвестиционные программы данных организаций, за выполнение которых должен отвечать муниципалитет, утвердивший их. Исполнение такой программы повысит эксплуатационные 
характеристики коммунальной инфраструктуры, а значит, приведёт к уменьшению неплатежей, неисполнение же - повлечёт принудительное снижение тарифов. Единственной объективной предпосылкой к росту тарифа можно допустить влияние инфляции в стране (официальной, а лучше - реальной);

- изменение существующей схемы управления жилым фондом. В настоящее время в России функционирует следующая схема управления многоквартирными домами (МКД): управляющая компания (УК) - МКД. При такой схеме объектом управляет только управляющая компания, т.е. субъектом управления становится только УК без собственников. Такая схема приводит на практике к многочисленным негативным последствиям. Для многоквартирного дома коллективной формы собственности с большим числом квартир наиболее эффективной схемой управления является ТСЖ - УК - МКД. Управление многоквартирным домом является специфической профессиональной деятельностью, требующей специальных знаний и технологий, которые отсутствуют у обычных жильцов, составляющих правление $\quad$ ТСЖ.

\section{ВЫВОД}

Таким образом, введение института обязательного саморегулирования в ЖКХ мегаполиса с учетом вышеизложенного позволит:

1. д долгосрочно планировать свою деятельность управляющим компаниям и брать на себя многолетние инвестиционные проекты (энергоэффективность, санация зданий, модернизация инфраструктуры);

2. снизить административное давление и уменьшить коррупционную ёмкость рынка жилищно-коммунальных услуг, на который будет допущено сообщество профессионалов и собственников, т.е. субъектов наиболее заинтересованных в эффективности всего процесса управления;

3. определить понятие безопасности, и, как следствие, рисков управления и эксплуатации. Это откроет возможность для соразмерного страхования имущества и ответственности за него;

4. ввести материальную ответственность управляющих компаний;

5. обеспечить полную информационная открытость членов СРО, что позволит показать структуру цен, обеспечить полную прозрачность деятельности управляющей компании, которая, как субъект заинтересованный в получении прибыли, получит правильную мотивацию к внедрению новых технологий, позволяющих без увеличения тарифа снизить затраты на содержание многоквартирного дома;

6. обеспечить участие управляющих компаний и их саморегулируемых организаций в качестве представителей собственников в отношениях с монополистами и прочими коммерческими структурами (банки, расчетные центры и т.д.). При этом наличие коллективного «рычага» в виде объединения УК в СРО приведет к снижению комиссий по обслуживанию переводов «квартплаты» и т.д.; 
7. создать общественный регулятор отношений в ЖКХ мегаполиса.

Определенность в отношениях позволит ввести установление различного порядка оказания услуг в этой сфере и порядка осуществления ответственности всех участников этих отношений в зависимости от того, к какой категории относится конкретная услуга:

- услуги, связанные с исполнением публично-правовых (вытекающих из закона) требований технических регламентов безопасности зданий (в разрезе механической, инженерной, экологической и эпидемиологической безопасности зданий);

- услуги «монополистов» (поставщиков ресурсов/услуг - тепла, воды, канализации, связи и т.п.), связанные с исполнением гражданско-правовых требований (вытекающих из Договора поставки, в условиях правил тарифного ценообразования);

- услуги прочие (уборка, косметический ремонт общего имущества и т.п.), связанные с исполнением гражданско-правовых требований, вытекающих из Договора на оказание услуг.

\section{ЛИТЕРАТУРА}

1. Федеральный закон «О саморегулируемых организациях» от 01.12.2007г. № 315-Ф3.

2. Кондрашов, А.О. Самоуправление и саморегулирование в системе ЖКХ мегаполиса // IX Всероссийская научно-теоретическая конференция «Политические, экономические и социокультурные аспекты регионального управления на Европейском севере». - Сыктывкар. 2011. - С. 37-41.

3. Кондрашов, А.О. Проблемы саморегулирования управляющих компаний в ЖКХ Российской Федерации.- Научно образовательный центр «Технологии таможенного сервиса». Санкт-Петербургский научно-исследовательский центр «Кристал». Совместный сборник научных трудов № 2. СПб.: СПбГУСЭ, 2011, - С.253-256.

4. Кондрашов, А.О. Зарубежный опыт функционирования саморегулируемых организаций в ЖКХ.- Научно образовательный центр «Технологии таможенного сервиса». Санкт-Петербургский научно-исследовательский центр «Кристал». Совместный сборник научных трудов № 2. СПб.: СПбГУСЭ, 2011, - С. 256- 258.

5. Назаров, Д. Оценка финансовых последствий и возможных рисков введения саморегулирования. - СПб.- 2011.

6. Дроздов, Г.Д. Инновационные энергосберегающие технологии в системе ЖКХ/ Г.Д. Дроздов. Инновации. 2009. № 5. С.100-102

7. Дроздов, Г.Д. Система диспетчеризации жилых зданий на основе новых информационных технологий / Г.Д. Дроздов. Инновации. 2011. № 11. С.115-119

8. Дроздов, Г.Д. Инновации в строительном комплексе и модернизация подготовки современных менеджеров / Проблемы современной экономики 2011. № 3. С. 239-241 